\title{
原著論文
}

\section{咀嚼運動の分析による咀嚼機能の 客観的評価に関する研究}

\author{
志賀 博 小林 義典 \\ An Objective Evaluation of Masticatory \\ Function by Analysis of Masticatory Movements
}

Hiroshi Shiga and Yoshinori Kobayashi

\begin{abstract}
In order to establish an objectively evaluating method for masticatory function ${ }^{-}$an automatic masticatory movement analyzing system was developed. Using this system the differences in the masticatory movement between normal subjects and craniomandibular disorder (CMD) patients were analyzed.

1. A system was developed that can change the analog signals of masticatory movement to digital signals, establish threshold value, and automatically evaluate the average path of the opening and closing movement and the rhythm of the opening, closing and occluding phase.

2. No significant differences were found in the opening, closing, and occluding time when the system or the degimatic caliper was used in analyzing masticatory strokes.

3. The ten strokes beginning the fifth stroke of chewing gum were the most stable in both rhythm and path.

4. There were significant differences between CMD patients and normal subjects in the indicators for the stability of rhythm and path.

5. The stability of rhythm and path was considered normal if the indicators were within one standard deviation, and for the rhythm, if 3 out of 4 indicators, and for the path, if 2 out of 3 indicators were within normal range.

6. A radar chart was formulated for an objective evaluation of masticatory function.
\end{abstract}

Key words : automatic masticatory movement analyzing system, masticatory function, average path, chewing rhythm, chewing path 


\section{I. 緒 言}

咀嚼機能は, 頭・顠部の諸器官, 特に歯, 歯肉, 歯周 組織，額骨，䫑関節，口唇，㛲，口蓋，咀礵筋，顔面筋， 頚筋, 舌, 大小口腔腺, 咽頭などの末梢効果器系, これ らから起こる感覚入力系, 中枢処理系, その運動出力系 が総合的に㗢いて，食物の性状に適したリズミカルな咀 嚼運動が行われるという咀嚼システムによって営まれ る"1. また, 末梢効果器系のうち, 特に歯, 顎関節, 顎 筋の三要素は密に関連していて生理的な条件下ではバラ ンスが保たれているが，1つの要素が異常に刺激される と, 他の要素にも病的に作用し，三要素に加え頳筋を支 配している神経系で構成される機能的咬合系全体として の機能異常が出現する ${ }^{2)}$. したがって, 咀嚼機能を客観 的に評価するためには，咀嚼運動を分析することが極め て重要である.

かかる見地から，近年，咀嚼運動におけるリズムと経 路の観察に基つく安定性に関する研究が比較的多く行わ れるようになり ${ }^{3 \sim 17)}$, 客観的評価の可能性が示唆される

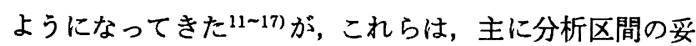
当性を明示せずにリズムの安定性について検索したもの であり，また経路の安定性についても，経路の概形の定 性的検索にとどまっている.

一方, 最近では, エレクトロニクスの発達とコンピュ 一タの普及に伴い，咀噮運動におけるリズムと経路の定 量的評価が試みられるようになってきた ${ }^{18 \sim 20)}$. しかしな がら,これらは, 経路を代表する平均経路全体を分析し

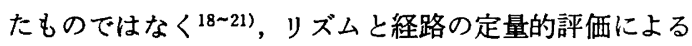
咀嚼機能の客観的評価法が確立されるまでに至っていな いのが現状である。

そこで, 本研究は, 咀嚼運動におけるリズムと経路の 定量的評価による咀䔣機能の客観的評価法の確立を目的 として, はじめに咀嚼運動自動分析装置の開発を行い, ついでこの装置を用いて咀嚼運動における正常者と咀嚼 系機能障害患者との差異を分析し, 咀嚼機能の客観的評 価のための表示法を検索した. また，この表示法を咀嚼 運動自動分析装置に含めてシステム化した自動処理を試 みた。

\section{II. 研究方法およひ結果}

\section{1. 咀踾運動自動分析装置の開発}

まずはじめに，咀嗳運動におけるリズムと経路を定量
的かつ自動的に分析できる装置の開発を試みた.

1）咀嚼運動自動分析装置の構成

(1) 構成機器

システムの構成機器は, ハードウェアとソフトウェア から構成される.

a. ハードウェア

ハードウェアは, Myotronics 社製 Mandibular kinesiograph (Model K-5), 日本電気社製パーソナル・コン ピュータ PC-9801 VM21, ならびにマイクロサイエンス 社製 A/D コンバーターDAS-1898 XPC である.

b. ソフトウェア

ソフトウェアは, BASIC 言語 (日本電気社製 N 88 BASIC）によりプログラムを作成し, MS-DOS 上で作動 するようにコンパイル処理を行った. 以降のプログラム の作成は, この方法で行ったが, A/D 変換部分のプログ

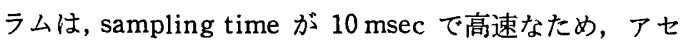
ンブリ言語で記述後, BASIC プログラム上に組み込ん だ.

(2) 装置の開発手順

装置は,以下の手順で開発した。

a. A/D (アナログ ・ デジタル) 変換

Mandibular Kinesiograph で記録した下顎運動のアナ ログ信号を A/D コンバーターにより sample 数 2000, sampling time $10 \mathrm{msec}$ にてデジタル信号に変換した.

b. リズムを表わす指標

リズムを表す指標は，開口相，閉口相，咬合相の各時 間とそれらの和, すなわち cycle time とした. また, 開口相, 閉口相, 咬合相の各開始点の認識は, 垂直成分 に対して以下の方法によった.

a) 測定原点の設定

測定原点は，記録開始 5 秒後からの 5 秒間における垂 直成分の最小値とした (図 1). この点は, 記録開始 5 秒 後からの 5 秒間における咀嚼運動中, 最も上方である.

b）初期闇値の設定と閉口相開始点の認識

食品の介在や咬合問題の存在により，下狉が中心咬合 位に至らない場合でも，咀嚼ストロークを確実に各相に 分解するため, 初期閾值を測定原点の下方 $2 \mathrm{~mm}$ の位置 に設定し (図 1), この䦭値から咀嚼ストローク中の一次 開口相開始点と一次咬合相開始点を算出した (図 1). つ いで, 各ストロークの一次開口相開始点から一次咬合相 開始点までの垂直成分で最も下方にある点を算出し，閉 口相開始点とした（図 1).

c) 咬合相の認識

一次咬合相開始点から一次開口相開始点まで，すなわ 


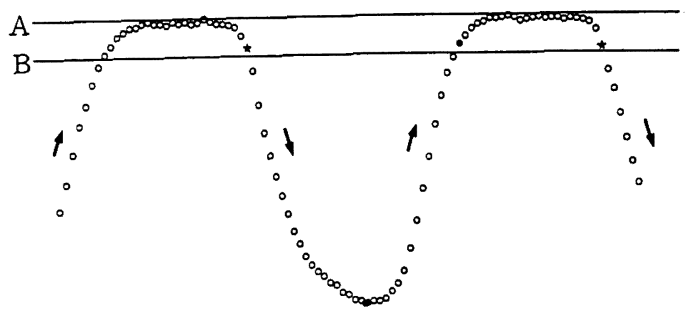

図 1 測定原点, 初期闘值の設定と一次開口相開始点, 一次咬 合相開始点, 閉口相開始点の認識

$\bigcirc:$ 下顎運動の垂直成分, $\mathrm{A}:$ 測定原点, $\mathrm{B}:$ 初期閥値,

: 一次咬合相開始点, $\star$ : 一次開口相開始点, 口: 閉 口相開始点

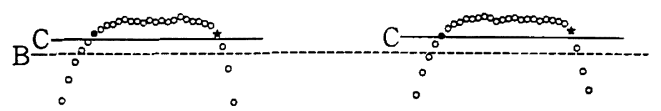

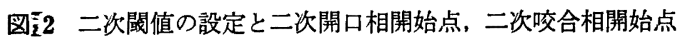
の認識

$\mathrm{C}:$ 二次闒値, $\mathrm{O}$ 二次咬合相開始点, $\star$ : 二次開口相 開始点

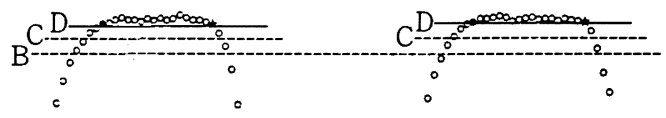

図 3 最終間值の設定と開口相開始点, 咬合相開始点の認識 $\mathrm{D}$ : 最終閾値, 0 : 咬合相開始点, $\star$ : 開口相開始点

ち初期間値より上方にある垂直成分の全データの平均值 を求め, 二次閾值とした. この二次闘值から二次開口相 開始点と二次咬合相開始点を算出した (図 2).ついで, 二次咬合相開始点から二次開口相開始点まで，すなわち 二次闒值より上方の垂直成分の全データの平均値と標準 偏差を求め, この両者を加算して最終閾值とし, 最終閾 值から各ストローク中の開口相開始点と咬合相開始点を 算出した (図 3).

c. リズムの安定性を表わす指標の作成

咀嚼開始後の任意のストロークからの 10 ストローク の各ストロークにおける開口相, 閉口相, 咬合相の各時 間と cycle time を算出後, 10 ストロークの平均值と標 準偏差から変動係数を求め, リズムの安定性の指標とし た.

d. 経路と速度成分の定性的表示

a）各ストロークの表示

咀嚼運動を開口相, 閉口相, 咬合相の各開始点の認識 により各ストロークに分解し, 前頭面と矢状面の経路と 速度成分を定性的に表示した. 各ストロークのグラフィ ック表示 (図 4-A) は，各ストロークの閉口相開始点を 境にして開口路と閉口路とを点で色分けした. またここ

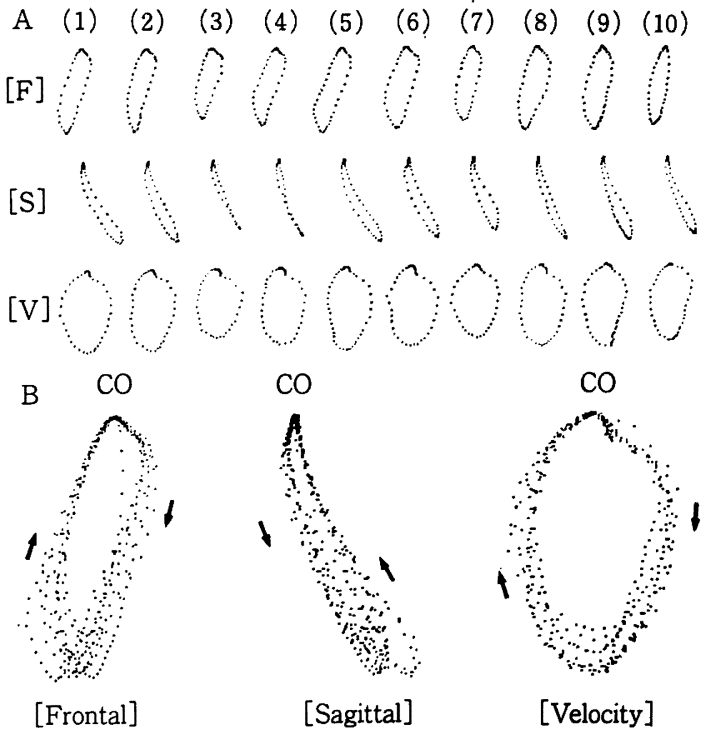

図 4 任意のストロークからの 10 ストロークにおける前頭面, 矢状面, 速度の各ストローク表示 (A) と重ね合わせ表示 (B) $[\mathrm{F}]$ : 前頭面, $[\mathrm{S}]$ : 矢状面, $[\mathrm{V}]$ : 速度

の点表示は, sampling time $10 \mathrm{msec} て ゙ \mathrm{~A} / \mathrm{D}$ 変換したた め, 隣り合う 2 点間の距離が $10 \mathrm{msec}$ における下皕の 移動量を示す. すなわち, 隣り合う 2 点が接近していれ ば, 運動速度が遅く, 離れていれば運動速度が速いこと を示す.

\section{b）重ね合わせ表示}

任意のストロークからの 10 ストロークは, 重ね合わ せ表示ができるようにし (図 4-B), 各ストロークの表示 と同様に開口路と閉口路とを色分けした。

\section{e. 経路を表わす指標}

経路を表わす指標は，前頭面における平均経路とし. 以下の方法によって求めた.

咀嚼開始後の任意のストロークからの 10 ストローク の各ストロークにおける中心咬合位を基準として，前頭 面投影した開閉口路を上下的に 10 分割し，各分割点の 座標值 $(X, Y)$ を求めた（図 5 ).

ついで, 各座標值の 10 ストロークの平均値と標準 偏 差を算出し，この平均值点を連ね，平均経路とした．ま た, 平均経路上の各平均值点に水平方向と垂直方向の標 準偏差を合わせてグラフ表示し, 経路の安定性を視覚的 に観察できるようにした（図 6-A).

なお，矢状面における平均経路は，矢状面投影した開 閉口路について（図 6-B），また開閉口速度は, 開閉口時 速度成分と開口距離の垂直成分について (図 6-C), 上記 と同様な手順で行った. 
A

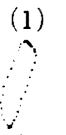

(5)

(9)
(2)

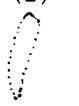

(b)

(10)
(3)

(7)
(4)

I

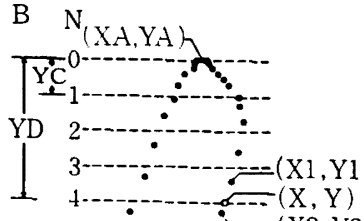

(8)

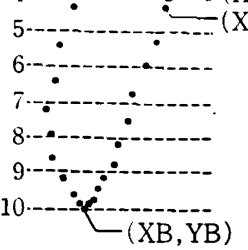

$(\mathrm{X} 2,)^{2}$

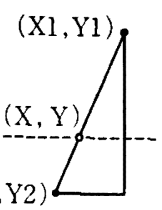

$(\mathrm{Y} 2-\mathrm{Y} 1) \times \mathrm{X1}-\mathrm{X})=(\mathrm{Y}-\mathrm{Y} 1) \times \mathrm{YI}-\mathrm{X} \mathrm{X}\rangle$

$\mathrm{X}=\mathrm{X} 1-(\mathrm{X} 1-\mathrm{X} 2) \times \frac{(\mathrm{Y}-\mathrm{Y} 1)}{\left(\mathrm{Y} 2-\mathrm{Y}_{1}\right)}$

$\mathrm{Y}=\mathrm{YA}+\mathrm{YD}=\mathrm{YA}+\mathrm{N} \times \mathrm{YC}$
$\mathrm{C}_{\mathrm{N}}$

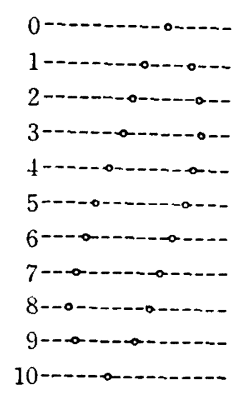

図 51 つのストロークの中心咬合位から開口位までを上下的に 10 分割した各分割点の座標値の算出 $\mathrm{A}$ : 咀䟠開始後の任意のストロークからの 10 ストローク，B：開口時の第 4 分割点の座標 $(\mathrm{X}, \mathrm{Y})$ とその算出式, (XA, YA) : 中心咬合位, (XB, YB) : 開口位, $\mathrm{C}$ : 各分割点の座標点

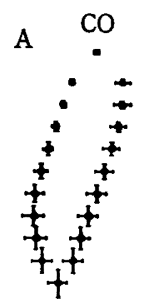

$\mathrm{B}$
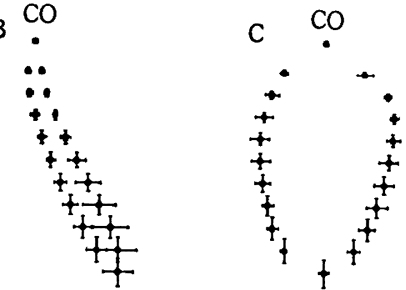

㢴

咀礵開始後の任意のストロークからの 10 ストロークの 平均経路ならびに標準偏差

$\mathrm{A}$ : 前頭面, $\mathrm{B}:$ 矢状面, $\mathrm{C}:$ 開閉口時速度

f. 経路の安定性を表わす指標の作成

上記の平均経路上の各平均値点における開口時の水平 方向の標準偏差の平均を開口時側方成分, 閉口時の水平 方向の標準偏差の平均を閉口時側方成分，開閉口時の垂 直方向の標準偏差の平均を垂直成分としてそれぞれ算出 後, これらの各成分を開口量で除算し (以後 $\mathrm{SD} / \mathrm{OD}$ と 略す), これを経路の安定性の指標とした. なお, 開口 量は, 平均経路の最下方点として算出した.

2）開口相，閉口相，咬合相の各開始点の自動認識と 平均経路の妥当性の検討

本研究の開口相, 閉口相, 咬合相の各開始点の自動認 識と平均経路の妥当性を検討するため, 以下の実験を行 った.

(1) 実験方法

a. 被験者と被験食品

被験者は, 22〜28 歳 (平均 23.5 歳) の日本歯科大学 歯学部の学生と職員の中から無作為に 20 名を選択した.

被験食品は, チューイン・ガム（ワーナー・ランバー 卜社製） 1 枚を記録前に約 1 分間咀嚼させ，軟化したも のを用いた.

b. 記録方法

被験者は, 頭部を固定せずに, フランクフルト平面が
水平となるようにリラックスさせた状態で歯科用治療椅 子に坐らせた。咀嚼運動は, Mandibular Kinesiograph K-5 型を用いて, 主咀嚼側咀嚼時の 30 ストロークにお ける切歯点の運動を TEAC 社製データーレコーダー （XR-50）に記録した.

c. 分析方法

a) 開口相, 閉口相, 咬合相の各時間の自動認識によ る計測結果とノギスによる実測結果との比較

被験者 20 名の咀嚼開始後 30 ストロークに扔ける開口 相, 閉口相, 咬合相の各時間について, 本研究の自動認 識による計測結果とノギスによる実測結果とを比較し た.なお,ノギスによる実測值は, 術者 3 名の実測值の ばらつきがきわめて小さかったので， 3 名の実測值の平 均を代表值として適用した.

b）本研究方法による平均経路と他の研究方法による 平均経路との比較

被験者 20 名の咀嚼開始後 30 ストロークについて，本 研究方法と他の研究方法, 寸なわち Mongini1 ${ }^{18)}$, 森 ${ }^{199}$, 瑞森ら ${ }^{20)}$ の研究方法により, それぞれ平均経路を求め, 両者を前頭面における経路の重㸚合わせ表示と比較し た.

(2) 結果と小括

a. 開口相，閉口相，咬合相の各時間の自動認識によ る計測結果とノギスによる実測結果との比較

各被験者の計測方法別にみた開口相，閉口相，咬合相 の各時間と全被験者の計測方法間における対応ある平均 值の差の検定結果は, 表 1 に示寸.

開口相, 閉口相, 咬合相の各時間は, 各被験者ともに 自動認識による計測結果とノギスによる実測結果とがほ ぼ同じ值を示し, 両計測方法間に有意差が認められず, t-value も0.4〜0.6できわめて小さな値であった.この 
$64-1116$

補緅誌

表 1 各被匼者の計測方法別にみた開口相時間, 閉口相時間, 咬合相時間と全被験者の計測方法間における対応ある平 均値の美の検定結果 Mechanical：自動認識による計測 結果, Manual：ノギスによる実測結果

(msec)

\begin{tabular}{|c|c|c|c|c|c|c|}
\hline & \multicolumn{2}{|c|}{ Opening time } & \multicolumn{2}{|c|}{ Closing time } & \multicolumn{2}{|c|}{ Occluding time } \\
\hline Sub. & $\begin{array}{l}\text { Mecha- } \\
\text { nical }\end{array}$ & Manual & $\begin{array}{l}\text { Mecha- } \\
\text { nical }\end{array}$ & Manual & $\begin{array}{l}\text { Mecha- } \\
\text { nical }\end{array}$ & Manual \\
\hline 1 & 213 & 209 & 180 & 182 & 177 & 181 \\
\hline 2 & 180 & 181 & 196 & 199 & 193 & 190 \\
\hline 3 & 213 & 211 & 186 & 189 & 149 & 150 \\
\hline 4 & 170 & 167 & 169 & 170 & 176 & 180 \\
\hline 5 & 210 & 212 & 234 & 231 & 294 & 303 \\
\hline 6 & 191 & 195 & 216 & 218 & 148 & 144 \\
\hline 7 & 140 & 139 & 128 & 130 & 209 & 214 \\
\hline 8 & 184 & 193 & 207 & 210 & 137 & 128 \\
\hline 9 & 185 & 187 & 184 & 177 & 135 & 134 \\
\hline 10 & 206 & 210 & 184 & 188 & 167 & 160 \\
\hline 11 & 194 & 187 & 185 & 186 & 137 & 141 \\
\hline 12 & 178 & 180 & 254 & 252 & 157 & 155 \\
\hline 13 & 185 & 184 & 215 & 218 & 183 & 178 \\
\hline 14 & 207 & 212 & 175 & 173 & 195 & 190 \\
\hline 15 & 152 & 148 & 146 & 142 & 195 & 203 \\
\hline 16 & 153 & 157 & 129 & 127 & 184 & 179 \\
\hline 17 & 159 & 161 & 176 & 181 & 156 & 151 \\
\hline 18 & 175 & 172 & 238 & 221 & $2+1$ & 246 \\
\hline 19 & 176 & 175 & 150 & 151 & 176 & 173 \\
\hline 20 & 205 & 207 & 193 & 197 & 188 & 185 \\
\hline t-value & -0. & 647 & -0 . & 440 & 0.0 & 16 \\
\hline
\end{tabular}

結果は, 自動認識による計測結果がノギスによる実測結 果と一致することを示すものであり，本研究における開 口相, 閉口相, 咬合相の各開始点の自動認識の妥当性が 明らかになった。

b. 本研究方法による平均経路と他の研究方法による 平均経路との比較

全被験者の前頭面における経路の重ね合わせ表示, 本 研究方法による平均経路, ならびに他の研究方法 ${ }^{18 \sim 20)}$ に よる平均経路は，図 7 に示す.

開口量がほぼ一定である場合（被験者 1〜6）には，両 平均経路は, ともに重社合わせ表示した経路の水平的か つ垂直的なほぼ中間点を通過し，方法間による差が認め られなかった. 一方, 開口量が変動する場 合 (被験 者 7〜20)には, 平均経路は, 本研究方法では開口量が一定 である場合と同様に重ね合わせ表示した経路の水平的か つ垂直的なほぼ中間点を通過したが，他の研究方法 ${ }^{18 ~ 20)}$ では開口位付近できわめて不規則となり, 開口から閉口 への変曲点が消失し, 開口から閉口への変曲点付近の平 均経路を示すことが不可能だった。これらのことから， 本研究方法による平均経路は, 経路の水平的かつ垂直的 なほぽ中間点を通過することが確認された。
34 巻 6 号 (1990)

\section{3）分析区間の設定}

適切な分析区間を設定するために，次の実験を行っ た.

（1）実験方法

a. 被験者

被験者は, 全身と咀噯系に臨床的な異常が認められな い22 28 歳 (平均 23.7 歳) の日本歯科大学歯学部の学 生と職員 20 名を選択した。

b. 被験食品と記録方法

被験食品と記録方法は，上記の実験と同様である.

c. 分析方法

各被験者別に咀礵開始から 1 ストロークごとに順次起 点とした各連続 10 ストローク（21 シリーズ）について, リズムの安定性を表す指標（開口相時間，閉口相時間， 咬合相時間, cycle time の各変動係数) と経路の安定性 を表す指標（開口時側方成分，閉口時側方成分，垂直成 分の各 $\mathrm{SD} / \mathrm{OD}$ )をそれぞれ算出後, 全被験者の平均を求 め, 各連続 10 ストローク間で比較した.

(2) 結果と小括

a.リズムの安定性

全被験者でみた咀礵開始から 1 ストロークごとに順次 起点とした各連続 10 ストロークにおける開口相時間, 閉口相時間, 咬合相時間, cycle time の各変動倸数の平 均は, 図 8 に示す.

開口相時間と cycle time の各変動係数の平均は, 第 5 からの 10 ストローク，また閉口相時間と咬合相時 間の 各変動係数の平均は, 第 6 からの 10 ストロークがそれ ぞれ最小値を示し，その後徐々に不安定になった．閉口 相時間と咬合相時間の各变動係数の平均は，第 5 からの 10 ストロークが第 6 からの 10 ストロークに近似寸る值 を示した. したがって, 30 回の咀緭ストロークにおける 第 5 からの 10 ストロークのリズムが, 最も安定すると いえる.

b. 経路の安定性

全被験者でみた咀霞開始から1ストロークごとに順次 起点とした各連続 10 ストロークにおける開口時側方成 分, 閉口時側方成分, 垂直成分の各 $\mathrm{SD} / \mathrm{OD}$ の平均は, 図 9 に示す.

開口時側方成分と垂直成分の各 SD/OD の平均は, 第 5 からの 10 ストローク，また閉口時側方成分の SD/OD の平均は，第6からの 10 ストロークでそれぞれ最小值 を示し, その後徐々に不安定になった. 閉口時側方成分 の SD/OD の平均は, 第 5 からの 10 ストロークが第 6 からの 10 ストロークに近似する値を示した. したがっ 
[Sub. 1]
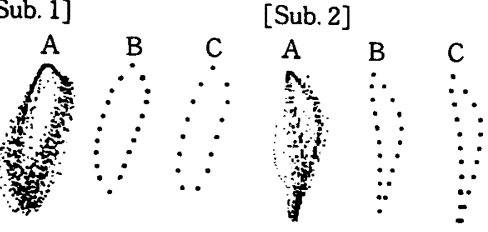

[Sub. 3]

[Sub. 4]
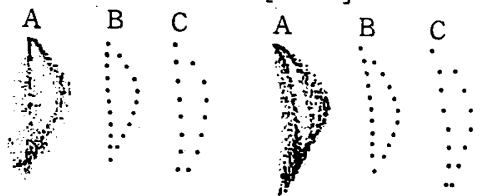

[Sub. 5]

[Sub. 6]

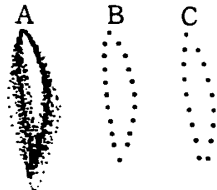

[Sub. 7]

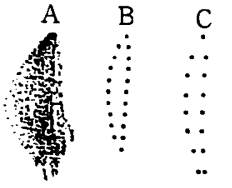

[Sub. 8]

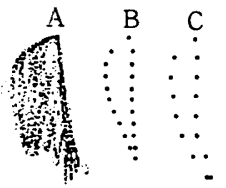

[Sub. 9]

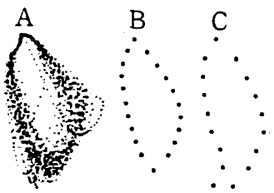

Sub. 12]

\section{[Sub. 12]}

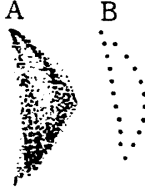

$\mathrm{C}$
$\because$
$\because$
$\because$
[Sub. 13]

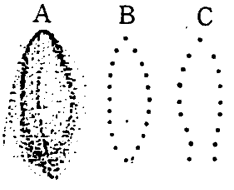

[Sub. 14]

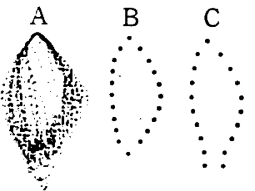

[Sub. 18]

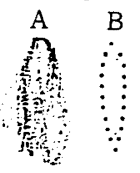

[Sub. 19]

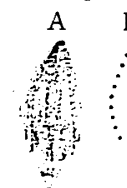

[Sub. 17]

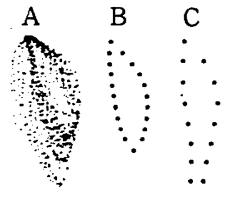

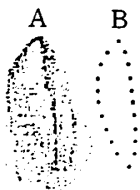

$\mathrm{C}$
$\vdots$
$\vdots$
$\vdots$

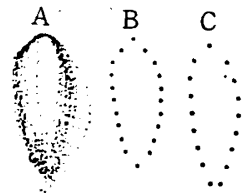

[Sub. 10]

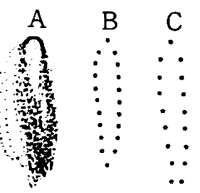

[Sub. 15]

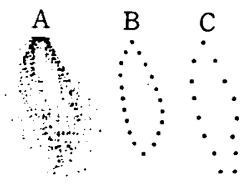

[Sub. 20]

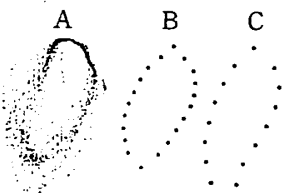

図 7 全被験者の前頭面における経路の重外合わせ表示 (A), 本研究方法による 平均経路 (B), ならびに他の研究方法による平均経路 (C)

て,30 回の咀嚼ストロークにおける第 5 からの 10 スト ロークの経路が, 最も安定するといえる.

これらの結果から, 咀嚼運動の分析区間は, 咀嚼開始 後第 5 からの 10 ストロークに決定すべきことが明 確に なったので，この区間を自動的に抽出できるようにし た.

以上のように, 本咀嚼運動自動分析装置は, 咀嚼運動 におけるリズムと経路を定量的かつ正確に分析するため の十分な性能を有している.

\section{2. 咀㖟機能の客観的評価のための表示法の検索と表 示法の自動処理}

咀嚼運動自動分析装膡の開発により, 咀嚼運動におけ るリズムと経路を定量的かつ正確に分析することが可能 となったので, 次に咀緭機能の客観的評価のための表示 法を設定する目的で, 咀緭運動自動分析装置を用いて, 咀嚼運動における正常者と咀獣系機能障害患者との差異 を分析した. また，この表示法を咀嚼運動自動分析装置 に含めてシステム化した自動処理を試みた.

\section{1）実験方法 \\ (1) 被験者}

被験者は, 全身と咀嚼采に臨床的な異常が認められな い21 32 歳 (平均 23.9 歳) の日本歯科大学歯学部の学 生と職員 67 名を正常者群, また昭和 60 年 4 月から同 62 年 10 月に方けて日本歯科大学歯学部病院補緅科に来院 した 19〜36 歳 (平均 26.3 歳) の咀嚼系機能障害患者の 中から, 顎関節部の疼痛, 顎関節雑音, 下狉運動制限の 3 症状のうち， 2 症状以上を有する患者 54 名を患者群 としてそれぞれ選択した. なお，歯の久損が 1 歯以内 で，その部が修復されていることを条件にした.

\section{（2）被験食品と記録方法}

被験食品と記録方法は, 前述の実験と同様であるが, 患者群では, 右側咀緭時と左側咀嚼時を記録した.

\section{(3) 分析方法}

正常者 67 名と患者 54 名の咀嚼開始後 第 5 からの 10 ストロークについて, リズムの安定性を表す指標（開口 相時間，閉口相時間，咬合相時間, cycle time の各変動 係数) と経路の安定性を表す指標（開口時側方成分, 閉 


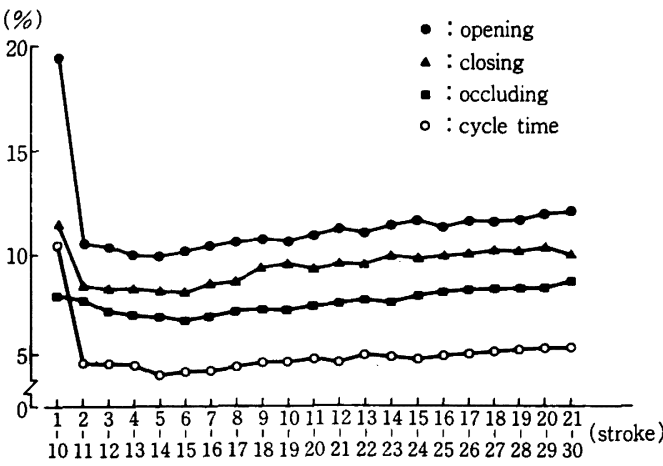

図 8 全被験者でみた咀獣開始から1ストロークごとに順次起 点とした各連続 10 ストロークにおける開口相時間, 閉 口相時間, 咬合相時間, cycle time の各変動係数の平 均 $(n=20)$

口時側方成分，垂直成分の各 SD/OD）をそれぞれ算出 後，両群間で比較した．また，正常範囲を設定するた め, 正常者群に扔けるリズムと経路の安定性を表す各 指標の平均値と標準偏差から mean-1 SD と mean +1 SD の両值を求め, mean-1 SD 以下, mean \pm 1 SD 以内, mean +1 SD 以上の各範囲にある正常者群の被験者数を 調べた.さらに，正常範囲の妥当性を検討するために, 全被験者についてリズムと経路の安定性を表す指標ごと に正常範囲にある被験者数を調べた。最後に，これらを 咀嚼運動自動分析装置に含めてシステム化し，自動処理 する表示法を検討した.

2) 結果と小括

(1) リズムの安定性

正常者群と患者群における開口相，閉口相，咬合相の 各時間と cycle time の各変動係数の平均値と標準偏差, ならびに両群間における対応のない平均值の差の検定結 果は, 表 2 と図 10 に示す.

開口相時間，閉口相時間，咬合相時間, cycle time の 各変動係数は，正常者群では $10.8 ， 9.1 ， 7.6 ， 4.5 \%$ だ ったが，患者群では $25.1 ， 15.3 ， 14.7 ， 11.2 \%$ で，正 常者群よりも著明に大きく，両群間に有意差が認められ た.

\section{(2) 経路の安定性}

正常者群と患者群における開口時側方成分, 閉口時側 方成分, 垂直成分の各 $\mathrm{SD} / \mathrm{OD}$ の平均值と標準偏差, な らびに両群間における対応のない平均值の差の検定結果 は，表 2 と図 10 に示す.

開口時側方成分, 閉口時側方成分, 垂直成分の各 $\mathrm{SD} /$ OD は，正常者群ではそれぞれ $3.2 ， 3.6 ， 3.8 \%$ だった が，患者群ではそれぞれ $7.2,6.8,7.5 \%$ で，正常者群
34 巻 6 号 (1990)

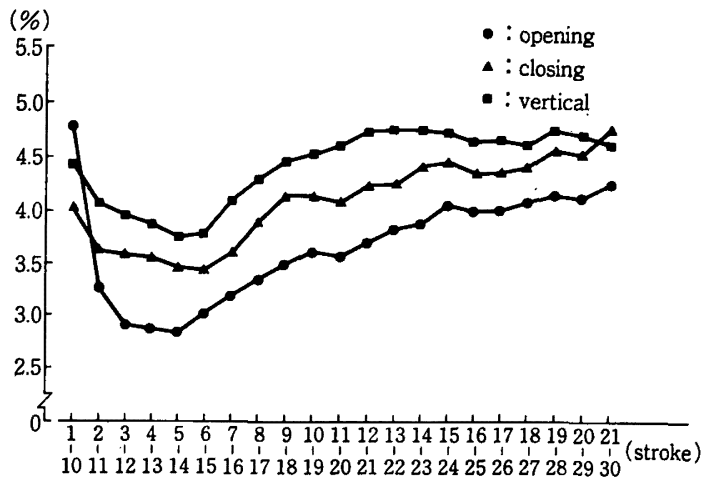

図 9 全被験者でみた咀霹開始から1ストロークごとに順次起 点とした各連続 10 ストロークにおける開口時側方成分, 開口時側方成分, 垂直成分の各 $\mathrm{SD} / \mathrm{OD}$ の平均 $(n=20)$

よりも著明に大きく，両群間に有意差が認められた。

（3）正常者群におけるリズムと経路の安定性を表す各 指標值の被験者数

リズムと経路の安定性を表す各指標値における被験者 数の結果は, 表 3 と 4 に示す。

各指標値が mean-1 SD 以下であった被験者は 16〜20 名, mean $\pm 1 \mathrm{SD}$ 以内であった被験者は 44〜46 名だった が, mean+1 SD 以上であった被験者は 3〜6 名できわめ て少なかった。 そこで，リズムと経路を表す各指標值が mean $+1 \mathrm{SD}$ 以内を仮の正常範囲として設定した.

（4）設定したリズムと経路の安定性を表す各指標值の 正常範囲の妥当性の検討

全被験者におけるリズムと経路の安定性を表す各指標 值別にみた被験者数は，表 5 と 6 に示す。

正常者群における設定した正常範囲を示す被験 者 数 は，リズムでは 4 指標すべてが 67 名中 47 名， 4 指標中 3 指標が残りの 20 名，また経路では 3 指標すべてが 67 名中 54 名, 3 指標中 2 指標が残りの 13 名であった。す なわち，すべての正常者は，リズムでは 4 指標中 3 指標 以上，経路では 3 指標中 2 指標以上がそれぞれ設定した 正常範囲を示した.

一方，患者群における設定した正常笨囲を示す片側ご とにみた例数は，リズムでは 4 指標中 3 指標以上が 108 例 (54 名) 中 10 例，経路では 3 指標中 2 指標以上が 108 例中 14 例で少なく，これらはいずれもリズムと経 路 と の関連性が認められなかった．また，リズムの安定性を 表す 3 指標以上かつ経路の安定性を表す 2 指標以上が正 常範囲を示す例数は，わずか 2 例のみであり，この 2 例 はともに, 反対側の咀霞時で明らかな正常範囲外を示し たこれらのことから，設定した正常範囲は，リズムを 
表 2 正常者群と患者群における開口相時間, 閉口相時間, 咬合相時間, cycle time の各変動俰数と開 口時側方成分, 閉口時側方成分, 垂直成分の各 SD/OD の平均值と標㔼偏差ならびに両群間にお ける対応のない平均値の差の検定結果 Normal : 正常者群 $(n=67)$, Patients : 患者群 $(n=108)$

(\%)

\begin{tabular}{|c|c|c|c|c|c|c|c|c|c|c|c|c|c|c|}
\hline & \multicolumn{2}{|c|}{ Opening time } & \multicolumn{2}{|c|}{ Closing time } & \multicolumn{2}{|c|}{ Occluding time } & \multicolumn{2}{|c|}{ Cycle time } & \multicolumn{2}{|c|}{$\begin{array}{l}\text { Lateral element } \\
\text { in the opening } \\
\text { movement }\end{array}$} & \multicolumn{2}{|c|}{$\begin{array}{l}\text { Lateral element } \\
\text { in the closing } \\
\text { movement }\end{array}$} & \multicolumn{2}{|c|}{ Vertical element } \\
\hline & Normal & Patients & Normal & Patients & Normal & Patients & Normal & Patients & Normal & Patients & Normal & Patients & Normal & Patients \\
\hline Mean & 10.8 & 25.1 & 9.1 & 15.3 & 7.6 & 14.7 & 4.5 & 11.2 & 3.2 & 7.2 & 3.6 & 6.8 & 3.8 & 7.5 \\
\hline $\mathrm{SD}$ & 3.9 & 14.2 & 2.5 & 5.9 & 2.7 & 10.6 & 2.7 & 6.3 & 1.4 & 3.4 & 1.1 & 3.4 & 1.3 & 3.6 \\
\hline $\mathrm{t}$-value & \multicolumn{2}{|c|}{$9.881^{* *}$} & \multicolumn{2}{|c|}{$9.617^{* *}$} & \multicolumn{2}{|c|}{$6.623^{* *}$} & \multicolumn{2}{|c|}{$9.708^{* *}$} & \multicolumn{2}{|c|}{$10.835^{* *}$} & \multicolumn{2}{|c|}{$9.047^{* *}$} & \multicolumn{2}{|c|}{$9.709^{* *}$} \\
\hline
\end{tabular}

表 3 リズムの安定性を表わす各指標値における正常被験者数 Opening : 開口相時間, Closing : 閉口相時間, Occluding : 咬合相時間, Mean : 正常者 67 名の平均値

\begin{tabular}{ccccc}
\hline \hline & Opening & Closing & Occluding & Cycle time \\
\hline Mean-1SD以下 & 18 & 17 & 16 & 20 \\
\hline Mean 1 1SD以内 & 44 & 44 & 45 & 44 \\
\hline Mean+1SD以上 & 5 & 6 & 6 & 3 \\
\hline
\end{tabular}

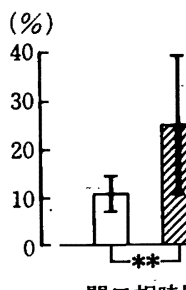

開口相時間

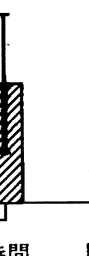

閉口相時間
表 4 経路の安定性を表わす各指標値における正常被験者数
Opening : 開口時側方成分, Closing : 閉口時側方成分,
Vertical : 垂直成分, Mean : 正常者 67 名の平均値

(名)

\begin{tabular}{lccc}
\hline & Opening & Closing & Vertical \\
\hline Mean-1SD 以下 & 17 & 19 & 17 \\
\hline Mean \pm 1SD 以内 & 46 & 45 & 44 \\
\hline Mean+1SD 以上 & 4 & 3 & 6 \\
\hline
\end{tabular}

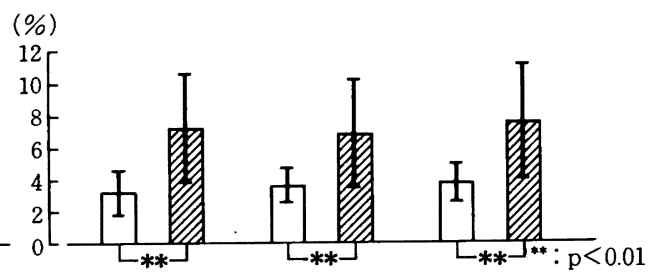

開口時側方成分 閉口時側方成分 垂直成分

図 10 正常者群と患者群における開口相時間, 閉口相時間, 咬合相時間, cycle time の各変動係数と 開口時側方成分, 閉口時側方成分, 垂直成分の各 $\mathrm{SD} / \mathrm{OD}$ の平均值と標準偏差

表す 4 指標中 3 指標以上, 経路の安定性を表す 3 指標中 2 指標以上という条件うけによって, 十分妥当性のある ことが明らかになった.

以上の結果から, 咀嚼系機能障害患者の咀嚼運動にお けるリズムと経路は，不安定であり，また正常者の咀嚼 運動におけるリズムと経路の安定性を表す各指標値の正 常範囲は, mean +1 SD 以内に設定すればよいことが明 らかになった.

（5）リズムと経路の安定性を表す各指標値の表示法と その自動処理の検討

上記の結果から, リズムと経路の安定性を表す各指標 值の正常範囲が明らかになったので, 咀嚼運動における リズムと経路を視党的に判定する正常者群の mean-1
$\mathrm{SD}$, mean, mean $+1 \mathrm{SD}$, また患者群の mean からレー ダーチャートを作成したところ（図 11）, 咀嚼運動にお けるリズムと経路の安定性について, 正常範囲か否かを 簡便かつ明確に表示することができた. さらに, このレ ーダーチャートをグラフ表示し, 被験者の数值データを 併せて表示できるように咀嚼運動自動分析装置に含めて システム化し, 咀嚼運動自動分析システムとして完成し た.

このシステムの完成により, 被験者の咀嚼運動を記録 後, 自動的に咀嚼ストロークを各ストロークに分解し, 咀嚼開始後第 5 からの 10 ストロークについて, 前頭面, 矢状面, ならびに速度の各ストロークの表示と重ね合わ せ表示，また前頭面と矢状面における平均経路と開閉口 
表 5 正常者群におけるリズムと経路の安定性を表す各指標 值別にみた例数

リズムの安定性

(例数)

\begin{tabular}{|c|c|c|c|c|}
\hline & $\begin{array}{l}4 \text { 指標加 } \\
\text { 正. 常筙围内 }\end{array}$ & $\begin{array}{l}3 \text { 指標かi } \\
\text { 正常範囲内 }\end{array}$ & \begin{tabular}{|l}
2 指摽が \\
正常䡉囲内
\end{tabular} & $\begin{array}{l}1 \text { 指標が } \\
\text { 正常範囲内 } \\
\end{array}$ \\
\hline $\begin{array}{l}3 \text { 指標力i } \\
\text { 正常船囲内 }\end{array}$ & 43 & 11 & 0 & 0 \\
\hline $\begin{array}{l}2 \text { 指標が } \\
\text { 正常筙围内 }\end{array}$ & 4 & 9 & 0 & 0 \\
\hline $\begin{array}{l}1 \text { 指標が } \\
\text { 正常䡉用内 }\end{array}$ & 0 & 0 & 0 & 0 \\
\hline
\end{tabular}

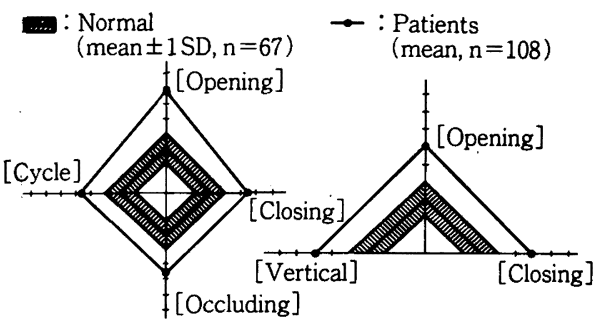

$$
\text { リズムの安定性経路の安定性 }
$$

図 11 リズムと経路の安定性を表すレーダーチャート

時速度，それらの数值表示，さらにリズムと経路の安定 性を評価するレーダーチャート上に被験者の数值データ を併せて表示することが可能になった.

\section{III. 考察}

\section{1. 咀嚼運動自動分析装置の開発について}

1） $\mathrm{A} / \mathrm{D}$ 変換について

$\mathrm{A} / \mathrm{D}$ 変換部分のプログラムは, A/D 変換時の sampling time が $10 \mathrm{msec}$ で高速なため, アセンブリ言語で 記述したが, A/D 変換時のデータを前もって BASIC 上 で配列宣言 (DA\% $(2000 ， 4))$ して確保したメモリ上に 格納するようにした.したがって，下預運動の垂直成分， 前後成分, 側方成分, 速度成分は, A/D 変換と同時にそ れぞれ DA\% $(1,1) \sim \mathrm{DA} \%(2000,1), \mathrm{DA} \%(1,2) \sim$ $\mathrm{DA} \%(2000,2), \mathrm{DA} \%(1,3) \sim \mathrm{DA} \%(2000,3), \mathrm{DA} \%$ $(1,4) \sim \mathrm{DA} \%(2000,4)$ に格納された. また，これらの データは, BSAVE, BLOAD 命令により,メモリ上の機 械語プログラムとしてディスクに保存あるいはディスク からの再生を行った. これらの操作により，処理時間を 短縮することができたものと考えられる.

2）開口相，閉口相，咬合相の各開始点の認識につい $\tau$

（1）測定原点の設定について

測定原点は，下䫟が硬い食品咀嚼時に食品の介在によ
34 巻 6 号 (1990)

表 6 患者群におけるリズムと経路の安定性を表す各指標値 別にみた例数

リズムの安定性

(例数)

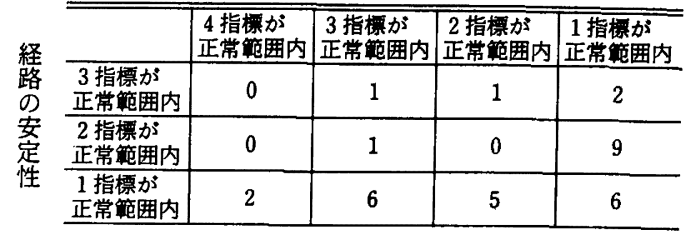

って中心咬合位に至らない場合や，有床義歯の沈下によ って習慣性咬合位よりも上方に至る場合が考えられるの で, 記録開始 5 秒後からの 5 秒間における咀嚼運動中の 最上方点に設定した．また，記録開始時のアーチファク 卜の混入を避け，確実な咀緭運動時の最上方点を求める ために, 記録開始 5 秒後からの 5 秒間において設定し た.

(2) 咬合相の認識法について

咀礵運動を正確に各相に分解できるか否かは，咬合相 をどのように認識するかということにかかっている，通 常，咬合相は，下頡運動の垂直成分から初期閥値を設定 後, 垂直成分の微分による速度間値を設定する方法がと られている ${ }^{15,22,23)}$ が，この方法では，もし速度闎值が小 さすぎると，咬合接触時に振動が生じた場合には，咬合 相を正確に認識できなくなり，逆に速度閥値が大きすぎ ると, 求めた咬合相が実際の咬合相よりも大きくなって しまう．また，初期閾値を大きく設定して速度閾值を設 定すると，咬合位付近での運動の制止や停止がある場合 には，咬合相を誤認する恐れがある，逆に，初期閾值を 小さく設定すると，食品の介在や咬合問題などによって 下䫑が中心咬合位に至らない場合には，咬合相を正確に 分解できなくなる.このような問題に配虑した秀島 ${ }^{24)}$ は, 硬性・破研性食品では速度変化が大きいことが予想され るので, 閉口相開始点を自動認識させるものの, 咬合相 を実測するという策を講じている. かかる点を考虑し， 本研究では，まず初期閥値を $2 \mathrm{~mm}$ に設定し，咀嘴スト ロークを確実に各ストロークに分解した。 ついで，初期 閥值より上方にある垂直成分の全データの平均值を求 め, これを 2 次閥値，さらに 2 次闇値より上方にある垂 直成分の全データの平均值と標準偏差を求め, この両者 を加算して最終閥值を設定し，閉口運動においてサンプ ル・ポイントが最終閥值を通過する点を咬合相開始点, 開口運動を逆行してサンプル・ポイントが最終閾値を通 過する点を開口相開始点とした. これは，下顎運動を開 口相, 閉口相, 咬合相に分解した場合には, 情報量が他 
の相よりも咬合相できわめて多いことを利用したもので ある.また, 2 次閥値については, 開口運動や閉口運動 の情報も多少存在するので，最終閵值を設定した.

ちなみに，本研究では，初期閾値を $2 \mathrm{~mm}$ に設定して いるので，下䫓が中心咬合位の下方 $2 \mathrm{~mm}$ までに至らな い場合には，咬合相を誤認する可能性が考えられる．し かしながら，正常者 67 名と咀嚼系機能障害患者 54 名に ついて，下說が中心咬合位に至らない例を調べたところ，

患者 1 名の 1 つのストロークで中心咬合位の下方約 1.8 $\mathrm{mm}$ が最大であり（図 12），それ以外はすべてが中心咬 合位から下方 $1.8 \mathrm{~mm}$ 以内であった.

したがって，本研究の咬合相の認識法は，下䅡が中心 咬合位に至らない場合，咬合接触時の振動がある場合， あるいは咬合位付近での運動の制止や停止がある場合で も，きわめて正確であり，有用性が高いと考えられる.

(3) 開口相, 閉口相, 咬合相の各時間の自動認識によ る計測結果とノギスによる実測結果との比較について

自動認識法は, 本来ヒトが行ら操作を機械が自動的に 行うことによって処理時間の短縮を可能にする方法であ り，ある一定の基準を設定することによって処理結果に 客観性をもたせるものではない，したがって，自動認識 法により得られた結果は, ヒトが行った結果と一致，あ るいは近似していなければならない.

本研究の被験者 20 名の咀鮁開始後 30 ストロークにお ける開口相, 閉口相, 咬合相の各時間の自動認識は, い ずれの被験者でもノギスによる実測結果との間に有意差 が認められず, $\mathrm{t}$-value が 0.4〜0.6できわめて小さな值 であった.これは, 本研究の開口相, 閉口相, 咬合相の 各開始点の自動認識法が，咀嚼運動の分析に際して有用 性が高いことを示すものと考えられる.

3）本研究方法による平均経路と他の研究方法による 平均経路との比較について

近年のエレクトロニクスの発達により, 咀嚼運動の評 価に際して，平均経路を算出する定量的な分析が試みら

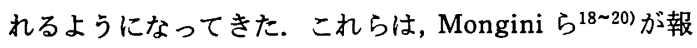
告している方法で，あらかじめ中心咬合位から下方へ向 かって 10〜20 $\mathrm{mm}$ の範囲に限定して水平に層分し, 各 層の平均点を設定している.

これらの方法による平均経路と本研究方法による平均 経路とを比較した結果, 両者の平均経路は, 開口量がほ ぼ一定である場合には，ともに重ね合わせ表示した経路 の水平的かつ垂直的なほほ中間点を通過し，方法の違い による差が認められなかったが, 開口量が変動する場合 には, 方法の違いによる差が認められた.すなわち, 本研

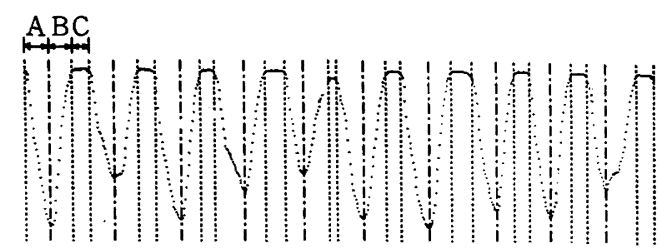

图 12 患者 1 における咀嚼運動自動分析システムを用いて自 動的に認識した開口相, 閉口相, 咬合相の各開始点 A : 開口相, B : 閉口相, C : 咬合相, ……運動の 垂直成分

究方法による平均経路は，開口量が一定である場合と同 様に重和合わせ表示した経路の水平的かつ垂直的なほぼ 中間点を通過したが, Mongini ら ${ }^{18-20)}$ の方法による平均 経路は, 開口位付近できわめて不規則となり, 開口から 閉口への変曲点が消失した. これは, Mongini $5^{18-20)}$ の 方法では, 既述のように平均経路の求め方が中心咬合位 から 10〜20 mm の範囲で限定し，しかもいずれのスト ロークについても同一の層分をしているためと考えられ る. 実際に, 咀嚼運動における正常者 8 名の経路を中心 咬合位から $1 \mathrm{~mm}$ おきに $20 \mathrm{~mm}$ 下方まで水平に層分し， 各層での平均值と標準偏差を求めた Mongini ${ }^{18)}$ は, 各 層の右側咀嚼時の咀礵ストロークの通過数が下方 $5 \mathrm{~mm}$ では開口時 191 , 閉口時 209 , 下方 $10 \mathrm{~mm}$ では開口時 186 , 閉口時 198 , 下方 $15 \mathrm{~mm}$ では開口時 155 , 閉口時 166 , 下方 $20 \mathrm{~mm}$ では開口時 35 , 閉口時 43 であったと 報告している，また，同様な方法で正常者 1 名の中心咬 合位から $0.4 \mathrm{~mm}$ おきに $12 \mathrm{~mm}$ 下方までの平均経路を 求めた瑞森ら ${ }^{20)}$ は, 各層の咀嚼ストロークの通過数が中 心咬合位から下方 $9.6 \mathrm{~mm}$ までは 17 であったが，下方 $10 \mathrm{~mm}$ では 14 , 下方 $10.4 \mathrm{~mm}$ では 9 , 下方 $12 \mathrm{~mm}$ では わずかに 2 だったと報告している.これらの報告は，と もに中心咬合位から最大開口位に向かうに従って咀嚼ス トロークの各層での通過数が減少し, その減少数が最大 開口位付近で著明であることを示しており，正常者でも 開口量が各ストロークによって変動することを意味して いる. このように, Mongini ら ${ }^{18 \sim 20)} の$ 方法では, 平均経 路全体から経路の安定性を観察することは, 不可能であ ろう.

これらのことから, 本研究で求めた平均経路は, 常に 経路の水平的かつ垂直的なほぼ中間点を通過し, 経路の 安定性について平均経路全体の安定性から観察すること が可能であり, 経路を表す指標として十分妥当性を示す ものと考えられる. 
4）リズムと経路の安定性を表す指標について

(1) リズムの安定性を表す指標について

リズムの安定性を定量的に表す指標として，下䪵運動 や筋活動の時間的要素の標準偏差 ${ }^{6,7,9)}$, 変動係数 ${ }^{10,12,15 \sim ~}$ 17)，あるいは平均変化量 ${ }^{4,5)}$ などが報告されている.これ らのうち, 標準偏差は観察值のばらつきの最も有効な記 述の仕方 ${ }^{25)}$ であるが，下頷運動や筋活動の時間的要素の 平均值に個人差がある場合には，その影響を直接的に受 けてしまう難点がある．また，平均変化量は，隣接変数 間の差の平均値であるため, 変数の配列順序に厳しく拘 束されるので, 適用が高い順序拘束性をもつ変数群に限 定される ${ }^{26)}$.

他方, 変動係数は相対的なばらつきを示す無名数で, 測度が異なる場合の比較に都合がよいという特徴を有す る25)。また，不正咬合者や咀嚼系機能障害患者における 下䫓運動や筋活動の時間的要素の変動係数は, 正常者の それよりも大きいことが明らかにされている3,7,10).これ らの被験者のすべてを対象とする本研究では，測度が明 らかに異なるので，開口相，閉口相，咬合相の各時間と ならびに cycle time の変動係数をリズムの安定性を表 す指標にした.

（2）経路の安定性を表す指標について

経路の安定性を定量的に表す指標として，経路を分割 して求めた平均点の標準偏差 ${ }^{18,20,21)}$ と変動係数 ${ }^{20)}$ が報告 されているが, 開口時の平均経路について, 標準偏差と 変動係数とを比較した著者ら ${ }^{27)}$ の研究では, 標準偏差は 側方への偏位量の影響を受けなかったのに対し，変動係 数は側方への偏位量が大きいと小さくなり, 逆に側方へ の偏位量が小さいと大きくなることが明らかになってい る.つまり, 変動係数は開口路の安定性とは関係なく, 開口路の概形によって変化する. したがって 標 準偏差 は, 変動係数よりも経路の安定性を表す指標として有効 と考えられる.

しかしながら, 開口量について, 正常者と咀唖系機能 障害患者とを比較した著者ら ${ }^{28)}$ の研究では, 両者間に有 意差が認められているので, 平均経路の概形の大きさの 違いによって影響を受ける標準偏差は, 本研究のような 正常者に加え, 咀嚼系機能障害患者も被験者としている 場合には，必ずしも安定性を表わす指標とはならないこ とが予測される。

かかる見地から，本研究では，平均経路の概形の大き さの違いによる影響を排除するため, 標準偏差を開口量 で除算し，これを経路の安定性の指標にした.
34 巻 6 号 (1990)

\section{5）被験食品について}

咀嚼運動は，食品の質や量によって変化することが明

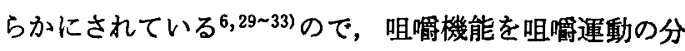
析，特に安定性から評価する際には，質や量ができる限 り変化しない被験食品が要求される. 咀嚼運動を分析す る際の被験食品としては，チーズ34)，カマボコ ${ }^{12)}$ ，チュ ーインガム ${ }^{8)}$, サラミンーセージ20), ニンジン35), ピー ナッッ5), クラッカー6), クリスピーブレッド ${ }^{18)}$, 生米 ${ }^{36)}$ などが使われているが，これらのうち，十分軟化したチ ニーインガムは, 咀嚼の進行に伴う硬さや量の変化が少 なく, リズムの安定性がよいので，分析に適しているこ とが示唆されており ${ }^{3,4,8,32)}$ ，最近の三田と小林 ${ }^{16)}$ の研究 でも，咀嚼機能の定量的評価には最適であることが確認 されている。

かかる理由から，本研究では，咀徱運動におおるリズ 么と経路の安定性を評価する目的のため, 被験食品は, 記録前に十分軟化したチューインガムを使用した.

6）分析区間の設定について

咀嚼運動の分析区間は, リズムが咀嚼開始初期と後半 で乱れること年,38), あるいは咀嚼開始初期では意識的要

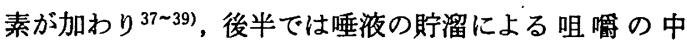

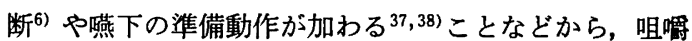
開始初期と後半, あるいは後半のみを除外した咀嚼開始 後 20 秒間 ${ }^{40)}$ ，咀嚼開始後 20 ストローク ${ }^{29)}$ ，咀虂開始 5 秒後からの 10 秒間 41 , 咀礵開始 5 秒後からの 10 スト口 一ク ${ }^{15,34,42)}$, 咀嚼開始後第 4 ストロークからの 10 ス卜 ローク ${ }^{16)}$, 咀嚼ストロークが安定してからの 10 ストロ 一ク10,12)などがあげられており，意見の一致がみられて いない. また，これらはほとんどが設定理由については 詳しく言及しておらず，実験的に調べた研究は，著者の 知る限りでは三田と小林 ${ }^{16)}$ の報告のみと思われる. この 研究では, 咀礵開始後の 30 ストロークについて, 第 1 から第 21 までの各連続 10 ストロークの咀礵筋筋活動時 間とその間隔時間の各変動係数を調べ，筋電図咀礵リズ ムは第 4 からの 10 ストロークが最も安定することを明 らかにしている.

本研究では，正常者 20 名の咀喂開始から 1 ストロー クごとに順次起点とした各連続 10 ストローク（21 シリ ーズ）について,リズムと経路の安定性を比較した結 果, リズム, 経路ともに咀嚼開始後第 5 ストロークから の 10 ストロークが最も安定していることが判明 した. この結果は, 上記の三田と小林 ${ }^{16)}$ の結果にほぼ一致し, 1 ストロークの違いは三田と小林 ${ }^{16)}$ の研究では笳電図の みを観察していることによるものと推察される. 
なお，結果に示したように，咀㘊開始からの30スト ローク中の後半は, リズム, 経路ともに徐々に不安定に なったが，これはガム咀礵を嚥下させずに30ストロー ク行わせたために, 後半のストロークでは唾液が貯溜 し，影響を及ぼしたものと推察される.

ちなみに，咀嚼運動中に自由に燕下をさせた場 合に は, 正常者では㖟下時を比較的判定し易いが, 咀嚼系に 機能異常あるいは機能障害が認められる患者では咀嚼運 動が不安定で運動の制止や停止が起こることが多く，嬹 下時の判定が困難となる. したがって, 咀嚼運動の機能 的分析に際しては，嚥下させずに咀嚼運動を記録すべき ものと思われる.

\section{2. 咀鮞機能の客観的評価のための表示法の検索と表 示法の自動処理について}

1）リズムの安定性について

正常者 19 名に右側と左側でガム咀嚼をさせた時の咀 緭運動におけるリズムの安定性を調べた瑞森ら 口相時間, 閉口相時間, 咬合相時間, cycle time の各変 動係数がそれぞれ 13.4，9.7，12.0，5.8\% であったと報 告している. 本研究の結果では, 正常者 67 名の開口相 時間, 閉口相時間, 咬合相時間, cycle time の各変動係 数は,それぞれ 10.8, 9.1, 7.6, 4.5\% で, cycle timeの 変動係数が瑞森ら ${ }^{43)}$ の報告と同様に最小值を示したが, 他の変動係数がいずれも瑞森ら ${ }^{43)}$ の報告よりも小さかっ た.これは, 本研究では, 正常者に主咀嚼側で咀緭させ ているのに対し, 瑞森ら ${ }^{43)}$ の研究では, 右側咀嚼と左側 咀嚼を指示しているために，咀嚼側間の機能的差異によ る結果が含まれていたものと考えられる.この咀嚼側間 の機能的差異については, 非主咀礵側咀嚼が主咀嚼側咀 嚼時よりも不安定になる可能性が Perry ら ${ }^{44)} に よ り$ 示 唆されており, 正常者 20 名の咀㩊運動における主咀嚼 側咀嚼時と非主咀嚼側咀嚼時の差異を定量的に比較した 最近の浜中ら ${ }^{45)}$ の研究でも, 咀嚼運動は非主咀嚼側咀嚼 時の方が主咀緭側咀嚼時よりも有意に不安定であること が確認されている.この問題を配虑し, 本研究では, 正 常者の主咀嚼側を正常像として選択した. 一方，患者で は，主咀嚼側を明示できない例数が多かったので，右側 咀䛓時と左側咀嚼時を記録した。

次に, 咀嚼系機能障害患者であるが, 54 名の開口相時 間, 閉口相時間, 咬合相時間, cycle time の各変動係数 は，それぞれ 25.1，15.3，14.7, 11.2\% で，いずれも正 常者群よりも著明に大きく，両群間に高度な有意差が認 められた.これは, 咀嚼系機能障害患者のリズムが, 正
常者のそれよりもきわめて不安定であることを示すもの と考えられる。

2）経路の安定性について

経路の安定性に関する定量的評価法として, 開口距離, 開口時最大側方距離, 閉口時最大側方距離などを指標と した分析は多い7,9,14,17)が, 開閉口路そのものを指標とし て分析した研究はきわめて少ない ${ }^{18 ~ 201}$. 後者の経路その ものの安定性を分析した報告のうち, 正常者 8 名の経路 を中心咬合位から $1 \mathrm{~mm}$ おきに $20 \mathrm{~mm}$ 下方まで水平に 層分し, 各層の点の平均值と標準偏 差を求めた Mongini $^{18)}$ は, 閉口時の標準偏差が開口時のそれよりも大き かったと報告し，開口運動は反復性があるが，閉口運動 は変動すると考察している. 本研究の結果では, 経路の 安定性を表す指標（開口時側方成分，閉口時側方成分， 垂直成分の各 $\mathrm{SD} / \mathrm{OD})$ は, 正常者でそれぞれ 3.2, 3.6, $3.8 \%$ を示し, 閉口時側方成分の $\mathrm{SD} / \mathrm{OD}$ は, Mongini ${ }^{18)}$ の報告と同様に開口時側方成分の $\mathrm{SD} / \mathrm{OD}$ よりもわずか に大きな值を示したが，両者間に有意差が認められなか った. この差異は, Mongini ${ }^{18)}$ の研究では被験者数が 8 名で, 少なかったためと推察される.また, 正常者 6 名の 右側咀緭時と左側咀獣時の経路を中心咬合位から $2 \mathrm{~mm}$ ごとに $10 \mathrm{~mm}$ 下方まで水平に層分し, 各層の点の標準 偏差を求めた瑞森ら ${ }^{20)}$ は, 最大值がほとんどの場 合 1 $\mathrm{mm}$ 末満で小さかったと報告している．本研究の結果で は，例えば開口量が $20 \mathrm{~mm}$ の正常者について，開口時 側方成分, 閉口時側方成分, 垂直成分の各標準偏差を算 出してみると，それぞれ $0.64,0.72,0.76 \mathrm{~mm}$ となり， 瑞森ら ${ }^{20)}$ の報告にほぼ一致し, きわめて小さな值を示し た. したがって，正常者の経路は，きわめて安定してお り，個人内でもごくわずかな変動があるものの，ほぼ同 一であると考えられる.

個人内の経路について, 正常者の咀嚼運動経路を視覚 的に観察した Ahlgren ${ }^{35)}$ は，規則的で調和がとれてい るが, 連続ストロークのパターンが絶えず変化し, 各個 のストロークが完全に一致することはなかったと報告し ており, その原因は, 咀嚼中における歯周組織, 舌, 歯 肉, 顎関節などの各受容器からの求心性入力に変動があ るためであると説明している．また，加藤 ${ }^{46)}$ は，咀㗖時 にヒトと同様な臼磨様の顎運動を行うウサギの三叉神経 知覚系分枝を切断し, 咀嚼側や筋活動の変化を調べた結 果, 三叉神経求心情報が咀嚼リズムを形成する機構に影 響を及ぼしていることが認められたと報告している.こ れらのことから，本研究の結果でみられた経路のごくわ ずかな変動は, チューインガムの形状が咀嚼中に変化す 
るために, 絶えず歯，口腔粘膜，舌，歯肉などへの刺激す なわち三叉神経求心情報が変化したためと考えられる.

本研究の結果でも, 正常者の経路における各ストロー ク間のごくわずかな変動が認められたことから，正常な 咀嚼運動を営むためには末梢からのフィードバック信号 が必要であり，その量がある闒值量以下であれば,かずか な変動を伴いながらもリズミカルな運動を維持し，末梢 からのフィードバック信号がある閵值量以上であれば, 経路の変動も増大することは容易に推察できる.このよ うに考えると，既述の唾液の貯溜によるものと推察した 最も安定する咀緭開始後の第 5 ストロークからの 10 ス トローク後の不安定性は, 唾液の貯溜が末梢からのフィ 一ドバック信号を増大させた結果として説明できよう.

次に, 咀喂系機能障害患者であるが, 本研究の結果で は, 開口時側方成分, 閉口時側方成分, 垂直成分の各 SD/OD は，いずれも正常者のそれらよりも著明に大き く, 両者間に高度な有意差が認められ, 経路がきわめて 不安定であることを示した. 本研究の咀嚼系機能障害患

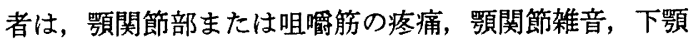
運動制限の 3 症状のうち， 2 症状以上を有するので，口 腔領域の感覚受容器からのフィードバック信号が多量 でリズミカルな運動を営むために必要な閥值量を越え たことにより,リズミカルな運動を維持できなくなり， きわめて不安定な経路を呈したものと考えられる.

3）リズムと経路の安定性を表す指標值の正常範囲に วいて

設定したリズムと経路の安定性を表す各指標値の正常 範囲は, リズムの安定性を表す 4 指標中 3 指標以上, 経 路の安定性を表す 3 指標中 2 指標以上という条件うけに よって十分妥当性のあることが明らかになったが，この 条件に適合する咀嚼系機能障害患者は, リズムと経路と を分けてみると，両者間に関連性が認められなかったも ののそれぞれ 10 例と 14 例存在した.これは, 咀䍛系機 能障害患者の中には, 少ないものの, リズムあるいは経 路のどちらか一方のみが安定する患者が存在することを 示している．したがって，咀嚼運動の分析による咀嚼機 能の評価に際しては, リズムあるいは経路のどちらか一 方のみならず，両者の安定性を分析しなければならない と考えられる.

また，同様な条件にリズム，経路ともに適合する咀㩊 系機能障害患者は，片側ごとにみて 2 例，すなわち 2 名 存在したが，いずれも反対側の咀嚼で明らかな正常範囲 外を示した．これはわずかではあるが，咀霹系機能障害 患者の咀虂運動の分析に際して, 片側のみならず, 左右
側でそれぞれ咀緭させ，記録する必要があることを示す ものと考えられる.

4）リズムと経路の安定性を表わす各指標値の表示法 とその自動処理について

既述のように，最近では，エレクトロニクスの発達と コンピュータの普及に伴い，咀鲎運動におけるリズムと 経路の定量的評価が試みられるようになり ${ }^{18 \sim 20)}$ ，咀緭運 動の分析のためのコンピュータシステム18)，あるいは咀 嚼運動アナライジングシステム20)として報告されている が，正常範囲が明示されておらず，また経路の分析に際 して, 平均経路を求めているものの, 経路全体を分析し たものではなく，その数值データも出力されず，特に安 定性に影響を及ぼす分析区間についての表示も曖昧であ る. 本研究で完成した咀緭運動自動分析システムは, 咀 嚼運動に扔けるリズムと経路，また分析に必要な区間を 正確に自動認識するとともに, リズムと経路の安定性に ついて明確な正常範囲を基準に自動的かつ視覚的に表示 でき，さらに必要な数值データを簡便に出力できるよう にした. したがって, このシステムにより, 咀嚼運動に おけるリズムと経路の定量的評価を的確に行うことがで き, 咀霞機能の客観的評価法の一つとして有用性がきわ めて高いものと考えられる.

以上のことから, 本研究で完成した咀鲅運動自動分析 システムにより，咀礵運動におけるリズムと経路の定量 的評価による自動的かつ視覚的な咀嚼機能の客観的評価 法の確立が示唆された。

\section{IV. 結 論}

咀嚼運動におけるリズムと経路の定量的評価による咀 礵機能の客観的評価法の確立を目的として, 咀嚼運動自 動分析装置を開発し，これを用いて咀嚼運動における正 常者と咀嚼系機能障害患者との機能的差異を分析後, そ の表示法を検索し, 以下の結論を得た.

1. 咀嚼運動のアナログ信号をデジタル信号に変換 し, 閥値設定後, 開口相, 閉口相, 咬合相の各開始点の 認識から時間的要素によるリズムと前頭面における開閉 口路の上下的 10 分割点による平均経路を自動的に求め られる咀礵運動自動分析装置を開発できた。

2. 無作為に選択した 20 歳代の被験者 20 名のガム咀 啷開始後 30 ストロークにおける開口相，閉口相，咬合 相の各時間は, 同装置の計測とノギスによる実測との間 に有意差が認められなかった，また，同装置による平均 経路は, 開口量が変動しても重ね合わせ表示した経路の 
水平的, 垂直的中点を通過した.

3. 同装置で記録した 20 歳代の正常者 20 名のガム咀 嚼開始から 1 ストロークごとに順次起点とした各連 続 10 ストロークの 21 シリーズにおけるリズムと経路は,

第 5 からの 10 ストロークが最も安定していた.

4. 同装置による 21〜32 歳の正常者 67 名 と 19 36 歳の患者 54 名のガム咀哷開始後第 5 からの 10 ストロー クにおけるリズムの安定性を表す指標（開口相時間, 閉 口相時間, 咬合相時間, cycle time の各変動係数), また 経路の安定性を表す指標（開口時側方成分，閉口時側方 成分, 垂直成分の各 SD/OD) は, ともに患者群の方が正 常者群よりも有意に大きかった.

5. リズムと経路の安定性の正常範囲は，上記の各指 標值が mean $+1 \mathrm{SD}$ 以内で, リズムの安定性が 4 指標中 3 指標以上, 経路の安定性が 3 指標中 2 指標以上の条件 で設定できた.

6. 以上の結果から,リズムと経路の安定性を表す各 指標值における正常者群の mean-1 SD, mean, mean+ $1 \mathrm{SD}$, 患者群の mean によりレーダーチャートを作成し， 咀嚼運動におけるリズムと経路の安定性を視覚的かつ明 確に判定できることが明らかになった. また，このレー ダーチャート上に被験者の数值データを併せて表示でき るように咀嚼運動自動分析装置に含めてシステム化し, 咀嚼運動自動分析システムとして完成することができ た.

7.この咀嚼運動自動分析システムにより, 咀嚼運動 におけるリズムと経路の定量的評価による自動的かつ視 覚的な咀嚼機能の客観的評価法の確立が示唆された.

本論文の要旨は, 日本 ME 学会専門別研究会通回第 22 回頻口 腔機能研究会 (昭和 62 年 2 月 7 日), 昭和 62 年度日本歯科大学 齿学会第 362 回例会 (昭和 62 年 6 月 19 日), 日本 $M E$ 学会専門 別研究会通回第 28 回䫝口腔機能研究 会 (昭和 63 年 9 月 2 日), ならび第 80 回日本補緅歯科学会学術大会 (昭和 63 年 10 月 22 日）において発表した.

\section{文献}

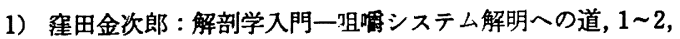
日本齿科評論社, 東京, 1988.

2）河村洋二郎：歯科学生のための口腔生理学, 158 232, 永 末書店, 京都, 1966.

3）関 秀孝 : 頻関節症の補経学的研究, 第 2 報䫑関節症患者 の筋電図学的研究, 口病誌, $35: 228 \sim 264,1968$.

4）宇贺村吉亮：咀灀リズムの筋電圆学的研究, 補緅誌, 16 :
275 292, 1973.

5）越智 寛, 平川光彦, 加登 㣚ほか：咬合異常者の補緅改 善例とその EMG 的観察, 阪大菌学誌, $19: 226 \sim 232$, 1974.

6）広瀬浩三 : 学童期に掞ける下穎前突者の頻・顔面頭蓋形態

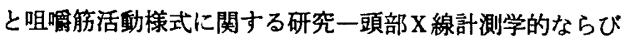
に筋電図学的研究一, 阪大歯学誌, $19: 58 \sim 80,1974$.

7) 加藤信次 : 額関節機能障害患者の切蒾点における呾嗳運動 について, 齿科医学, $41: 117 \sim 146,1978$.

8）柴田考典：下頻前突症における䫑運動機能に関する研究， 歯科学報, $81: 241 \sim 265,1981$.

9) Jemt, T. and Hedegård, B. : Reproducibility of chewing rhythm and of mandibular displacements during chewing, J Oral Rehabil, $9: 531 \sim 537,1982$.

10）尾崎佳孝：額関節症にみられる額運動異常に関する研究, 菌科学報, $83: 937 \sim 978,1983$.

11）井上健彦, 平井敏博, 又井直也ほか：咀嚼リズムに関する 一考察, 補緅誌, $26: 512 \sim 519,1982$.

12）米沢功至, 沢田 明, 内山洋一ほか：筋電図咀彩リズムを 用いた矠関節症患者の治療勃果の判定方法, 下矤運動機能 と EMG 論文集, 昭和 58 年度版, $59 \sim 64$, 下额運動機能 と EMG 研究会, 新渇, 1984.

13）又井直也：筋放電持続時間分割分析法からみた哟嚼リズム 一咀㗖の進行に伴う変動一, 補級誌, $28: 1118 \sim 1128,1984$.

14）伊崎克弥：ヒ卜の咀嗳運動経路の分析，一正常有歯影者お よび総義歯装着者について一, 補紴誌, $29: 657 \sim 674$, 1985.

15）瑞森崇弘：咀哷運動分析による額口腔機能診断に関する研 究, 阪大歯学誌, $32: 105 \sim 136,1987$.

16）三田貢司，小林義典：咀覆機能の脇電図学的評価に関する 臨床的研究, 齿学, $76: 711 \sim 760,1988$.

17）田中康隆：EMG Coordination Pattern からみた咀霞運動 の食品差について, 補緅誌, $32: 798 \sim 813,1988$.

18) Mongini, F. and Tempia-Valenta, G. : A graphic and statistical analysis of the chewing movements in function and dysfunction, J Craniomandib Pract, $2: 125 \sim$ $134,1984$.

19）森隆司：咀㗖運動経路の研究一空口側方滑走運動路およ び食品の影響一, 補緅誌, $26: 274 \sim 297 ， 1982$.

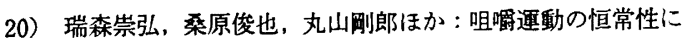
関する臨床的研究一同一食品における運動経路につい て一, 補緅誌, $29: 647 \sim 656,1985$.

21）桑原隆男, 瑞森崇弘, 丸山棡郎ほか：咀嘌運動に㧍ける運 動域ならびに閉口経路に関する研究, 補緅誌, $29: 106 \sim$ $115,1985$.

22）津賀一弘, 佐藤裕二, 津留宏道ほか: シグナルプロセッサ を用いた咀霖筋筋電龱解析システム, 下歌運動機能と EMG 論文集, 第 5 輯, $145 \sim 150$, 額口腔機能研究会, 新 
潟, 1987.

23）鹿野洋一, 田中久敏, 児玉厚三 : 総義歯咬合の維持に関す る臨床的研究，第一報正常有歯顎者と総義歯装着者の咀嚼 運動の比較, 下額運動機能と EMG 論文集. 第 7 輯, 9 16, 顎口腔機能研究会, 長崎, 1989.

24）秀島雅之：片側性臼歯部交刃咬合を伴う口蓋裂患者の咀嚼 運動について一曰歯部被蓋の違いが咀嚼パターンに及ぼす 影響一, 補緅誌, $33: 1168 \sim 1182,1989$.

25）辻 達彦：統計方法入門, 38 56, 金原出版, 東京, 1981 .

26）藤井弘之，佐藤博信，藤井哲則：事象の分散または再現性 を示す 2,3 のパラメーターについて, 補緅誌, $28: 703 \sim$ $708,1984$.

27）志賀 博, 浜中秀由喜, 小林義典ほか：咀嚼運動の機能的 分析, 第 10 報実験的咬合干涉付与前後における咀嚼運動 経路, 下䝷運動機能と EMG 論文集, 第 6 輯, 181 188, 頢口腔機能研究会, 長崎, 1988.

28）志賀 博, 浜中秀由喜, 小林義典ほか：咀嚼運動の機能的 分析一正常者と咀嚼采機能障害患者における咀喂ストロー クについて一, 下額運動機能と EMG 論文集, 第 6 輯,61 66, 顥口腔機能研究会, 長崎, 1988.

29）田中康隆, 虫本栄子, 三谷春保 : 咀嚼運動の EMG 的検査 に用いる各種被験食品の適量について, 歯科医学, 48 : $242 \sim 257,1985$.

30）中村隆志: 咀嚼運動調節機構の生理的特性に関する研究, 阪大歯学誌, $32: 36 \sim 55,1987$.

31）東 和生：咀嚼運動と咀嚼笳活動の関連性に関する臨床的 研究, 阪大歯学誌, $34: 26 \sim 63,1989$.

32）藍 稔: 切歯点部における咀嚼運動の解析, 補 緅 誌, 6 : 164 200, 1962.

33）川村貞行 : 咀霹時の下䫟切歯点の前頭面運動について, 歯 科医学, $36: 61 \sim 89,1973$.

34) Suit, S.R., Gibbs, C.H. and Benz, S.T. : Study of gliding tooth contacts during mastication, J Periodontol, 47 : 331 334, 1976.

35) Ahlgren, J. : Masticatory movements in man, edited by Anderson, D.J. and Matthews, B.. Mastication, 119
130, Wright, London, 1976.

36）石原寿郎, 平沼謙二, 橋本 譲ほか：生米を試験食品とす る咀嚼粉砝効率の算出基準について, 口病 誌, $26: 620$ $622,1959$.

37) Kawamura, Y., Kishi, K. and Nobuhara, M. et al : Studies on masticatory function, I. An electromyographic analysis of the chewing pattern of the normal occlusion and malocclusion, Med J Osaka Univ, 8 : 229 240, 1957.

38）延原通夫 : 不正咬合者の咀嚼機能に関する研究，I．算電 図による咀虂筋活動の分析, 阪大歯学誌, $3: 63 \sim 73,1958$.

39）藤本順三 : 頡運動機構の神経生理学的研究, 開口反射につ いて, 日本生理誌, $19: 1263 \sim 1271,1957$.

40) Pröschel, P. and Hofmann, M. : Frontal chewing patterns of the incisor point and their dependence on resistance of food and type of occlusion, J Prosthet Dent, $59: 617 \sim 624,1988$.

41）西尾公一, 宮内修平, 丸山剛郎：咀嗳運動に関する臨床的 研究一咬合様式との関連について一, 補 緅 誌, $30: 806 \sim$ 816, 1986.

42）桑原隆男, 高島史男, 丸山剛郎ほか：各種食品が咀嚼運動 に及ぼす影響に関する臨床的研究, 補緅誌, $31: 661 \sim 674$, 1987.

43）瑞森崇弘, 居相信之, 丸山郕郎ほか：咀緭運動の分析に現 れる咬合の異常, 第 2 報咀嚼運動分析項目と咬合の異常と の関連, 下額運動機能と EMG 論文集, 第 7 輯, $31 \sim 44$, 枵页口腔機能研究会, 長崎, 1989.

44) Perry, H.T. and Harris, S.C. : Role of the neuromuscular system in functional activity of the mandible, $\mathrm{J}$ Am Dent Assoc, $48: 665 \sim 673,1954$.

45）浜中秀由喜, 志賀 博, 小林義典ほか: 咀嚼運動の機能的 分析, 第 11 報 正常者の咀䇿運動経路における主咀嚼側 と非主咀獣側との差異（その 2), 補緅誌, $32 \cdot 79$ 回特別 号: 70, 1988.

46）加藤卓也：咀憡運動に対する三叉神経求心性情報の役割, 阪大歯学誌, $29: 129 \sim 137,1984$. 